\title{
A política industrial brasileira recente e as estratégias de inovação do setor moveleiro da região Oeste de Santa Catarina ${ }^{1}$
}

\author{
Darlan Christiano Kroth \\ Professor da Universidade Federal da Fronteira Sul (UFFS). \\ Endereço para contato: Rua Mato Grosso, 950E - Bairro Jardim Itália - Chapecó - SC. \\ CEP: 89802-300 - E-mail: darlanck@yahoo.com.br
}

Recebido em 12 de abril de 2016. Aceito em 27 de setembro de 2016.

\section{RESUMO}

Este trabalho tem como objetivo avaliar a influência das políticas industriais realizadas no Brasil pós-2003 sobre as estratégias de inovação da indústria moveleira da Região Oeste de Santa Catarina. Como estratégia empírica, foi realizada pesquisa de campo em 14 empresas exportadoras da região. As empresas entrevistadas foram selecionadas por meio de amostragem por voluntários e a coleta de dados foi realizada no período de janeiro a março de 2015. As entrevistas avaliaram um conjunto de três elementos relacionados ao tema: i) perfil; ii) estratégias de inovação das empresas; e iii) contribuição das ações de política industrial sobre as inovações. As principais conclusões referem que a indústria é caracterizada em sua maioria por empresas de pequeno porte, que fabricam móveis residenciais, estão no mercado há mais de 20 anos e não possuem uma política deliberada de inovação, embora acompanhem e realizem melhorias nos produtos e processos produtivos de forma constante. As principais inovações dizem respeito a "alteração tecnológica de produto" e "mudança tecnológica nos processos de produção" e, em menor grau, "inovação organizacional". Em termos de política industrial, os resultados apontaram que elas contribuíram de forma marginal para estimular suas inovações e que o aprimoramento da política deveria considerar programas de capacitação da mão de obra e aprimoramento da legislação trabalhista, linhas de crédito subsidiadas, subsídios fiscais e a melhoria em infraestrutura.

Palavras-chave: indústria de móveis, política industrial, Santa Catarina.

Classificação JEL: L68, L52, R11

\begin{abstract}
This study aims to evaluate the influence of industrial policies carried out in Brazil after 2003 on the furniture industry innovation strategies of the Santa Catarina West Region. As empirical strategy was field research conducted through semi-structured interviews in 14 export companies in the region. The interviews assessed a set of three elements related to the topic: i) characterization of the companies; ii) innovation strategies of enterprises; and, iii) contribution of industrial policy actions on innovations. The main findings relate to that industry is characterized mostly by small business that make residential furniture, and are in the market for over 20 years, do not have a deliberate policy of innovation, although monitor and carry out improvements in products and production processes steadily. The main changes refer to "technological change product" and "technological change in production processes" and to a lesser extent "organizational innovation". In terms of industrial policy, the results showed that they contributed marginally to stimulate their innovation and the improvement of policy should consider training programs to labor and improvement of labor legislation, lines of subsidized credit, tax subsidies and the improvement in infrastructure.
\end{abstract}

Key-words: furniture industry, industrial policy, the Santa Catarina state JEL Classification: L68, L52, R11

\footnotetext{
${ }^{1} \mathrm{O}$ autor agradece o apoio institucional da Universidade Federal da Fronteira Sul (UFFS) e os comentários e sugestões dos pareceristas anônimos e do prof. José Felipe de Almeida (PPGDE/UFPR).
} 


\section{INTRODUÇÃO}

O Brasil vivencia, desde 2003, uma retomada da utilização da política industrial para impor um novo vetor de desenvolvimento ao país. Desde esse ano, foram lançadas três políticas, após um interregno de mais de 20 anos: a Política Industrial, Tecnológica e de Comércio Exterior (PITCE), em 2004; a Política de Desenvolvimento Produtivo (PDP), em 2008; e o Plano Brasil Maior (PBM), em 2011. Essa estratégia de promover o desenvolvimento econômico com apoio de política industrial está alinhada com a experiência de vários países que observaram grandes taxas de crescimento econômico nos últimos 30 anos, como Coreia do Sul, China, Índia e Indonésia (CIMOLI et al., 2009).

Um dos setores industriais que recebeu atenção da política industrial recente é a indústria do mobiliário (móveis). Segundo Rosa et al. (2007) e Galinari et al. (2013) o setor de móveis está presente principalmente nas regiões Sudeste e Sul, onde estão localizados os principais polos produtores. Para esses autores, a indústria possui como características a alta intensidade de mão de obra e menor dinamismo tecnológico, se comparado com outros setores da economia. Soma-se a essas características, o fato do setor vir perdendo seu dinamismo no âmbito externo, apresentando déficit comercial a partir de 2013, conforme Ministério do Desenvolvimento, Indústria e Comércio Exterior (MDIC) (2014).

O estado de Santa Catarina possui uma indústria de móveis bastante dinâmica, sendo um dos maiores estados produtores do país. Em 2013 era o quinto estado em geração de empregos no setor e o segundo estado que mais exportava, perdendo a liderança em 2011 (MOVERGS, 2014). Entretanto, nos últimos anos a indústria do mobiliário catarinense vem se ressentindo da perda de competitividade, em virtude da apreciação da taxa de câmbio e da crise econômica mundial de 2008, fatores que, além de reduzirem mercados cativos no exterior, a exemplo do norte-americano, resultaram na perda de competitividade de muitas firmas catarinenses no cenário internacional.

A região Oeste catarinense se configura como um polo moveleiro importante do Estado, conforme Cario et al. (2008), só perdendo em tamanho para o polo de São Bento do Sul. A participação do setor de móveis da região Oeste sobre o setor de móveis catarinense passou de $25 \%$ em 2006 para 32\% em 2012, apresentando evolução de 40\% em seu valor adicionado no período de 2006 a 2013 (SANTA CATARINA, 2014). O melhor desempenho da região Oeste em relação aos outros polos do Estado decorre, sobretudo, da estratégia de vendas dessas firmas, voltada em maior grau para o mercado doméstico. Nesse sentido, as firmas do Oeste de Santa Catarina se beneficiaram do crescimento do setor imobiliário brasileiro dos últimos anos, o qual é grande demandante de móveis. Em que pese esse bom desempenho, deve-se avaliar em que medida as firmas regionais vem realizando investimentos para ampliar sua competitividade, com vistas a garantir sua participação no mercado doméstico, bem como para ampliar suas vendas no exterior.

Considerando a importância da política industrial e o desempenho e características do setor moveleiro, o presente estudo tem como objetivo principal avaliar em que medida as ações das políticas industriais realizadas pelo Brasil, a partir de 2004, estão articuladas e contribuíram com as estratégias de inovação do setor de móveis da região Oeste de Santa Catarina.

Para atingir o objetivo proposto, foi utilizada, como estratégia empírica, a realização de pesquisa de campo através de entrevista semiestruturada em quatorze empresas do setor. As empresas entrevistadas foram selecionadas através de amostragem por voluntários, de um conjunto de 54 empresas exportadoras no período de 2008 a 2013, conforme listadas pelo MDIC (2014). Nessa perspectiva, as entrevistas permitiram, primeiramente, levantar informações acerca das características gerais das firmas de móveis da mesorregião Oeste Catarinense e sua relação com os quesitos de inovação e competitividade. Em segundo lugar, de forma mais específica, a pesquisa 
possibilitou verificar junto às firmas exportadoras quais são suas estratégias de inovação, bem como avaliar em que medida as ações das políticas industriais contribuíram para a inovação do setor.

O desenvolvimento das questões do trabalho está estruturado da seguinte forma: após essa introdução, é realizada a revisão de literatura, em que na primeira subseção se avalia a parte teórica da política industrial com base na literatura de economia evolucionária neoschumpeteriana, e a segunda subseção apresenta as políticas industriais recentes e sua interface com o setor de móveis. A terceira seção é dedicada para a apresentação da metodologia. A quarta seção realiza uma análise descritiva de algumas estatísticas do setor de móveis e é realizada a discussão dos resultados da pesquisa. A quinta seção é reservada para a conclusão.

\section{A POLÍTICA INDUSTRIAL: ENTRE A TEORIA E A PRÁTICA}

Esta seção é dividida em duas partes, em que a primeira apresenta aspectos teóricos da política industrial, dando ênfase para a vertente evolucionária neoschumpeteriana ${ }^{2}$. A escolha por essa vertente decorre do fato de que ela defende a política industrial como um meio eficaz de estimular setores dinâmicos na economia e que, por sua vez, contribuem não somente para fomentar a indústria nacional, mas também para contribuir com o desenvolvimento econômico. A segunda parte faz uma apresentação sucinta das últimas três políticas industriais realizadas no Brasil, focalizando nas medidas direcionadas ao setor de móveis. Nesse sentido, a seção foi estruturada para fazer uma relação entre o que a literatura vem apontando como medidas mais adequadas para promover o desenvolvimento industrial e o que foi realizado pelo Brasil.

\subsection{Política industrial como estratégia de desenvolvimento}

De acordo com Suzigan e Furtado (2006), pode-se elencar duas vertentes principais na abordagem contemporânea da política industrial: a neoclássica e a evolucionária. A primeira reivindica uma importância menor para esse tipo de política econômica, dado sua afeição às forças de mercado, sendo seu receituário para a política a atuação sobre a resolução de falhas de mercado, como, por exemplo, assimetria de informações e/ou regulação de setores, através basicamente de ações com escopo sistêmico (ou horizontal, que será definido adiante). Importante frisar que, para essa escola, a efetivação da política se dará apenas quando as falhas de mercado possuírem custos maiores que os gerados pelas falhas de governo - em termos de burocracia e favorecimento de grupos.

A segunda vertente - na qual este trabalho se baseia - dá plena importância à política industrial e destaca o seu papel indutor, ou seja, seu poder de criar setores dinâmicos na economia, ou ainda, de criar novas vantagens comparativas, mais inclinadas à inovação. Nessa direção, a vertente evolucionária articula a tese schumpeteriana do papel estratégico da inovação no desenvolvimento econômico com a concepção teórica da economia evolucionária, conforme Nelson e Winter (1982).

2 O presente trabalho, ao lidar com políticas industriais focalizadas em inovação, tem como base o neoschumpeterianismo, mas dá maior ênfase aos elementos evolucionistas propriamente ditos, que por sua vez abarcam também aquela literatura. Para uma exposição sobre o evolucionismo na literatura econômica, ver Dosi e Nelson (1994). 
No arcabouço evolucionário, há dois elementos fundamentais a serem considerados: a empresa e o ambiente em que ela está inserida (o qual envolve suas instituições ${ }^{3}$ ). A interrelação entre esses dois elementos resultará em inovações e na difusão dessa inovação, que por sua vez promove mudanças estruturais na economia.

Esse processo de mudança estrutural e os fatores que o promovem tem como ponto de partida a tese de Schumpeter (1985). Para o autor, as mudanças são de natureza qualitativa (desenvolvimento portanto) e decorrem do emprego e/ou combinação de recursos diferentes para produzirem coisas novas. Esses fenômenos vão se formando ao longo do tempo, ou seja, a história importa e, a medida que se materializam, dão origem a novas oportunidades de desenvolvimento (uma espécie de efeito multiplicador). Para Schumpeter (1985), a variável determinante das mudanças é o empresário-empreendedor, ou seja, o empreendedor possui atributos/predicados que o impelem a criar o novo e estas inovações influenciam o ambiente econômico.

$\mathrm{Na}$ esteira da tese schumpeteriana, Penrose (1959) analisará o comportamento da firma em busca de seu crescimento. A autora dará maior ênfase para o papel da organização como um todo (a firma) e menos no papel individual do empresário. Nesses termos, para Schumpeter (1985), o empresário tem um papel mais direto, enquanto que, para Penrose (1959), o papel do empresário é diluído pela importância dos recursos da firma (recursos humanos e tecnológicos).

Para a autora, essa experiência e a atuação em conjunto desses recursos criam constantes oportunidades para o crescimento. Intrínseco nesse processo de criação de habilidades da equipe ao longo do tempo, são os conceitos de know-how, learning-by-doing e learning by interacting (que embora não sejam tratados especificamente pela autora, apresenta suas bases de estudo) ${ }^{4}$, são fatores muito significantes para os processos inovativos empresariais contemporâneos, como apresentados por Lundvall (1988) e Malerba e Orsenigo (1996).

O trabalho de Nelson e Winter (1982) traz novas e importantes contribuições ao estudo do comportamento da firma. Para os autores, os dois principais elementos que moldam o comportamento da firma e que podem criar, muitas vezes, as condições para o processo de mudança (ou inovação) se referem às habilidades dos recursos humanos da firma e as rotinas que são criadas no processo produtivo.

Esses autores darão ênfase, ainda, à importância do ambiente, isto é, fatores externos à firma também interferem na formação de suas habilidades. Dessa forma, as firmas estão em constante competição no mercado e, ao interagir com outras firmas e com as próprias instituições criadas, moldam-se na perspectiva de tirar proveito (ou criar vantagens competitivas) para não só se manterem no mercado, mas para ampliar seu espaço e seu tamanho (em termos de lucratividade). É dessa interrelação entre aspectos internos e externos da firma que se criarão oportunidades de inovação.

\footnotetext{
${ }^{3}$ Partindo da definição de Hodgson (2004), instituições são "sistemas duráveis de regras sociais estabelecidas e incorporadas que estruturam as interações sociais".

${ }^{4}$ De acordo com Lundvall (1988) e Malerba (1992), o know-how é o termo utilizado para descrever o conhecimento prático de como executar alguma tarefa, ou o conjunto de conhecimentos e habilidades de uma firma para executar determinada tecnologia. O know how também é conhecido como conhecimento tácito. O conhecimento tácito, por estar vinculado à experiência e aprendizado acumulado no tempo, não possui uma linguagem explícita para ser transferido para outra firma, portanto pode ser considerado como um recurso interno ou intangível da firma. O learning by doing (aprender fazendo) é o processo pelo qual os ganhos de produtividade ou inovações se dão via prática e/ou auto aperfeiçoamento, ou seja, das interações dentro do processo produtivo ou do processo de acúmulo de conhecimento. $\mathrm{O}$ learning by interacting é o processo de adquirir conhecimentos através da interação com outras firmas, seja pela via da imitação, seja pela via de parcerias (joint ventures) ou ainda de comentários (feedbacks) realizados por consumidores/usuários dos produtos.
} 
Como pode ser visto na abordagem acima, implícito na abordagem da influência do ambiente estão as instituições. Nesse sentido, Cimoli et al. (2009) argumentam que as instituições estão presentes em todos os processos de aprendizado tecnológico e de coordenação e mudança econômica. Para os autores, isso ocorre, pois em ambientes que possibilitem a experimentação de novos produtos, de novas técnicas de produção e de novas formas de organização, as interações econômicas se encontram ancoradas em uma rica malha de instituições. A importância das instituições, por sua vez, abriria espaço para atuação do Estado mediante o desenho de políticas públicas discricionárias.

Considerando o arcabouço evolucionário, uma definição de política industrial que se aproxima dessa vertente e que seguiremos neste trabalho é a de Suzigan e Furtado (2006), na qual a política industrial deve ser vista como um componente de uma estratégia de fortalecimento da indústria e parte indispensável de uma política mais geral de desenvolvimento, a qual, além do setor industrial, deve contemplar outros setores da economia e as instituições (em sua acepção mais geral) do país - incluindo instituições de apoio à indústria, infra-estrutura, normas e regulamentações. Isso faz da política industrial não um fim em si mesma, mas um meio destacado para o desenvolvimento.

Nessa mesma linha, associa-se o trabalho de Cimoli et al. (2009), o qual aponta que a política industrial, num conceito abrangente, deve contemplar não somente setores e atividades industriais indutoras de mudanças tecnológicas, mas também os ambientes econômico e institucional, uma vez que condicionam a evolução das estruturas de empresas e indústrias e da própria organização institucional. Assim, o objetivo específico da política industrial é, em última instância, fortalecer a competitividade da indústria, sempre com vistas a uma estratégia de desenvolvimento.

Ao apresentar o arcabouço teórico, é relevante distinguir os dois tipos de políticas que compreendem a política industrial, isto é, políticas horizontais e verticais (ou setoriais). As políticas horizontais estão voltadas para a economia em geral, atingem, portanto todos os setores industriais. Como exemplo dessa política (ou instrumentos utilizados), estão o aumento dos investimentos em educação, pesquisa e desenvolvimento (P\&D), melhoria na infraestrutura, aperfeiçoamento da política tributária, ampliação de medidas de cunho trabalhista e adequação de fontes de financiamento.

A política vertical é direcionada para setores específicos, geralmente eleitos como prioridades para o país. Também é uma forma de dinamizar setores para ficarem mais próximos de uma estrutura comparada aos países desenvolvidos em termos de setores mais modernos e se posicionar tão perto possível da cesta de exportação daqueles países. As políticas verticais estão relacionadas também com externalidades de aprendizado, ou seja, à promoção de indústrias nascentes. Essas políticas sempre se justificam quando a indústria é importante para outros setores da economia, ou seja, quando possui grandes efeitos sobre a cadeia produtiva do setor.

Para IEDI (2011a), apesar da distinção, os instrumentos horizontais e verticais devem ser utilizados de forma conjunta, complementares e de forma coordenada, visando sempre os objetivos propostos pelas políticas. Outro aspecto a considerar, é que as políticas horizontais têm natureza permanente e as setoriais seriam provisórias, ou seja, devem ter caráter temporário, com prazo definido de duração. Importante também é a definição clara dos incentivos concedidos aos setores escolhidos. 
Segundo Rodrik (2007), tanto o tipo da política como os instrumentos a serem utilizados, devem considerar que a política industrial não é única e aplicável a qualquer país. O autor aponta que não existe uma receita única, cada país deve construir a sua política industrial de acordo com sua realidade e momento histórico, tendo como premissas o diálogo entre os setores (construção de objetivos comuns) e uma coordenação forte, ou seja, o autor reivindica que o Estado precisa direcionar a gestão da política em uma figura representativa do país, como um ministro ou o próprio presidente da república.

Outra característica a ser observada no desenho da política industrial é considerar, segundo Metcalfe (1994), a formatação de um Sistema Nacional de Inovação (SNI), dado que a inovação e a difusão tecnológica são processos complementares e que se reforçam. O SNI representa o amplo conjunto de organizações que contribuem ou dão suporte para a geração de novos conhecimentos e aptidões, bem como para facilitar o espraiamento desse conhecimento para a economia e desta forma estimular o processo inovativo das empresas.

Nessa mesma linha, Melo et al. (2015, p. 17) enfatizam que,

\begin{abstract}
... a política industrial deve dar as condições necessárias para a consolidação de um sistema nacional de inovação, destacando a importância do setor privado nacional como principal agente responsável pela dinamização tecnológica da estrutura produtiva e consequente inserção internacional em mercados tecnologicamente mais avançados...

... Dessa forma, política industrial é entendida não apenas como a internalização de setores ausentes da matriz industrial e o incentivo a setores já instalados (embora também possa sê-lo), mas principalmente como a mobilização e implementação de mecanismos específicos para o desenvolvimento tecnológico, com o objetivo de reduzir as divergências competitivas e de padrões de desenvolvimento entre os países desenvolvidos e em desenvolvimento.
\end{abstract}

Um fator primordial para o sucesso do SNI é a coordenação dos trabalhos (ou da divisão de trabalho) realizados pelas diferentes organizações que o compõem (firmas privadas, universidades, laboratórios públicos e/ou agências de pesquisa), que possuem culturas e objetivos distintos e que respondem a diferentes incentivos (SUZIGAN; FURTADO, 2010). Aderente a essa preocupação e alinhado com Rodrik (2007), Metcalfe (1994), destaca que a política deve ser construída com a participação das organizações. Nesses termos, além do desenho da política e seus instrumentos, é apropriado ter um ator que coordene, anime e monitore os trabalhos, garantindo a variedade das inovações, sua difusão e a garantia de um processo de seleção com os menores custos sociais.

Metcalfe (1994) recomenda, por fim, que a política industrial deve considerar três elementos intrínsecos a cada firma e que interferem na decisão de inovar, quais sejam: i) a oportunidade para inovar; ii) os recursos disponíveis para inovar; e, iii) os incentivos para inovar (em termos de estratégias que a firma persegue e como reage a novas oportunidades).

Tendo avaliado a parte teórica da política industrial, com ênfase na vertente evolucionária, a próxima seção visa a apresentar sucintamente as principais medidas da política industrial brasileira recente, fazendo uma relação com o setor moveleiro.

\title{
2.2 As (novas) políticas industriais no Brasil e sua interface com o setor de móveis
}

Essa parte do texto foi reservada para apresentar uma síntese das três políticas industriais lançadas no Brasil no período pós-2003 e suas principais medidas relacionadas ao setor de móveis. Desse modo, pode-se elencar como principais pontos positivos dessas políticas industriais, a 
retomada da agenda industrial no país e a construção de um arranjo institucional para viabilizar a concretização dessa política.

Nesse sentido, dentro dos principais pontos positivos, a retomada da agenda da política industrial, a partir de 2004, demonstrou o esforço e o interesse do Estado em formular ações e estratégias para resgatar o desenvolvimento industrial brasileiro, o qual ficou ressentido ao longo dos anos 1990 com uma conjuntura de maior concorrência estrangeira. Dentro desse escopo de ações, pode-se citar a desoneração do investimento, da produção e das exportações, a tentativa de articular a política industrial com outros programas governamentais, buscando sinergias entre as ações, como o PAC e o PNE, e a criação e ampliação de linhas de crédito para financiar investimentos. Na área institucional, teve-se a edição das leis de Inovação (Lei n. 10.973/2004) e do Bem (Lei n. 11.196/2005) e a criação e/ou reorientação de entidades para assessorar e coordenar a execução da política industrial, a exemplo da reorientação estratégica de agências de Estado (BNDES, a FINEP e a APEX) e a criação da Agência Brasileira de Desenvolvimento Industrial (ABDI) e do Conselho Nacional de Desenvolvimento Industrial (CNDI) (FERRAZ, 2009; CANO; SILVA, 2010; IEDI, 2011b).

Por outro lado, em termos de continuidade da política industrial brasileira, é possível enumerar os seguintes pontos gerais que merecem aprimoramento: i) alinhar a política industrial com a agenda macroeconômica; ii) produzir instrumentos de estímulo à criação de setores de futuro e que promovam a competitividade sistêmica das cadeias produtivas; e iii) aprimorar a governança da política.

Com relação ao primeiro aspecto, Cano e Silva (2010, p.8) apontam que "as estratégias de desenvolvimento industrial não se fazem apenas com políticas industriais explícitas. Por melhor que seja seu desenho, deve contar com políticas macroeconômicas compatíveis. Do contrário, a política industrial implícita nestas últimas anula ou distorce as primeiras".

Em referência ao segundo, Shapiro (2013) argumenta que grande parte das medidas processadas como política industrial são, na realidade, demandas do ambiente de negócios não processadas por meio de reformas correspondentes, como é o caso da reforma tributária. Para o autor, como há dificuldades na realização dessas reformas, utiliza-se o espaço da política industrial para a realização de pequenos ajustamentos pontuais. A consequência disso é a contaminação da pauta da política industrial por agendas sistêmicas e horizontais e a realização de reformas institucionais, como, por exemplo, a reorientação estratégica das agências de Estado (BNDES, FINEP e APEX) e a construção de um marco regulatório visando a promover a inovação (Lei de Inovação (Lei n. 10.973/2004), Lei do Bem (Lei n. 11.196/2005) e Lei n. 11.080/2004 (constituição da Agência Brasileira de Desenvolvimento Industrial (ABDI)) em um ritmo de elevado gradualismo.

Por fim, sobre a governança da política, Suzigan e Furtado (2010) destacam que a ineficácia da organização institucional para implementar uma política industrial e tecnológica no Brasil decorre, em parte, de sua extrema complexidade e ausência de atuação sistêmica, pois há um número excessivo de órgãos que tendem a atuar de forma autônoma e assincrônica. Além disso, esses órgãos possuem precária capacidade de mobilizar recursos, quadros técnicos com pouca formação adequada que administram instrumentos dispersos e desarticulados. Outro problema relacionado à governança é a fragilidade do comando político e da coordenação das ações governamentais em articulação com o setor privado, protagonista maior dessa política. 
Dado esse panorama geral da política industrial brasileira recente, as próximas três subseções apresentam de forma sucinta os principais pontos das três políticas industriais lançadas no Brasil, a partir de 2003: PITCE (2004), PDP (2008) e PBM (2011), dando ênfase para as ações direcionadas ao setor de móveis.

\subsubsection{Política Industrial, Tecnológica e de Comércio Exterior (PITCE) - 2004}

A PITCE foi lançada em março de 2004 no primeiro governo do presidente Lula, encerrando no país um período de mais de 20 anos sem uma política industrial. Considerando que nesse período a indústria mundial passou por avanços significativos em termos de reposicionamento e progresso tecnológico, bem como as várias transformações que a economia brasileira enfrentou (crise da dívida, instabilidade macroeconômica, diversos planos de estabilização e abertura comercial), a PITCE foi recebida com entusiasmo por vários setores da sociedade (principalmente acadêmica e industrial).

De acordo com Suzigan e Furtado (2006), a construção da PITCE partiu de uma avaliação e diálogo com a sociedade, tendo suas metas/objetivos alinhadas com o novo paradigma tecnológico e gargalos que a economia brasileira deveria superar. Em linhas gerais, a PITCE foi marcada por políticas horizontais, pautada em três principais objetivos: a modernização industrial, visando o aumento da eficiência produtiva; a geração de inovações; e a ampliação das exportações, principalmente de bens com maior valor agregado ${ }^{5}$.

Com relação às medidas para o setor de móveis, destaca-se que este não foi objeto central de uma ação específica, embora tenha sido contemplado através das medidas horizontais, como por exemplo: ações de apoio as exportações de micro e pequenas empresas, algumas linhas de financiamento de máquinas (via BNDES) e para inovação (via FINEP) e apoio a Arranjos Produtivos (APLs).

O desempenho do setor de móveis no período de 2004 a 2008 não foi favorável, demonstrando que o mesmo enfrentou dificuldades com a nova configuração da conjuntura internacional. Nesse sentido, a participação do setor no Valor de Transformação da Indústria do país passou de 2,6\% para 2,2\% (PIA/IBGE), o número de empregos passou de 458,6 mil para 435,3 mil (MTE/RAIS) e o volume exportado passou de US\$ 3,9 bilhões para US\$ 3,7 bilhões (MDIC). É possível que em virtude desse desempenho do setor, o mesmo tenha sido inserido dentro dos objetivos da nova política industrial, a PDP de 2008.

\subsubsection{Política de Desenvolvimento Produtivo (PDP) - 2008}

A PDP, lançada em maio de 2008, partiu de um diagnóstico do setor industrial realizado por meio de discussões entre seus segmentos e propôs metas e objetivos mais concretos e pragmáticos para sua execução (IEDI, 2011). Dessa maneira, a PDP inicia com a vantagem do legado deixado pela PITCE (2004) e de uma conjuntura econômica mais favorável (crescimento da produção industrial por 23 trimestres consecutivos e crescimento do investimento e do comércio exterior), embora já fosse vislumbrado um cenário difícil em virtude do início da crise financeira internacional.

Os principais pontos basilares da PDP, conforme BRASIL (2008), referem-se aos seus objetivos, divididos em duas partes: o objetivo geral ou central, com desafios e macrometas; e os

\footnotetext{
${ }^{5}$ Conforme Vermulm (2004), a PITCE contemplava 57 medidas e 11 programas articulados em três eixos principais.
} 
objetivos estratégicos, ancorados em cinco estratégias, considerando políticas em três níveis: ações sistêmicas, destaques estratégicos e programas estruturais. A PDP contemplava também amplo esforço em aperfeiçoar a capacidade de coordenação e gestão da política, delineando as ações de cada esfera do governo e responsabilidades do gerenciamento do processo ${ }^{6}$.

O setor de móveis foi contemplado pela PDP na dimensão estratégica "Programas para Fortalecer a Competitividade", que tinha como foco os complexos produtivos com potencial exportador e/ou com potencial de gerar efeitos de encadeamento sobre o conjunto da estrutura industrial. Nessa direção, os objetivos propostos para o setor, conforme BRASIL (2008), foram: (i) conquistar mercado de móveis de alto padrão nos EUA e Europa e ampliar participação de móveis em geral em novos mercados; (ii) desenvolvimento dos APLs; (iii) construir competitividade (produção sustentável e valorização do design brasileiro); e (iv) promover o acesso doméstico a móveis com qualidade e preços competitivos.

Conforme o relatório BRASIL (2010), a agenda de ação do setor de madeira e móveis contou com cinco ações e treze medidas. O relatório ressalta que a agenda demorou muito para ser elaborada, em função das dificuldades de articulação no âmbito do Fórum de Competitividade.

A primeira ação contemplou o estímulo à comercialização dos produtos (tanto interna como externamente) e contava com o maior número de medidas, oito medidas. As medidas implementadas foram: i) ampliação de recursos da linha de financiamento "Novo Revitaliza"; ii) extensão do prazo de financiamento do PROEX; iii) redução da alíquota do IPI.

Outras três medidas tiveram encaminhamentos e ficaram aguardando novas definições, como: i) incorporar mobiliário básico na construção das residências destinadas ao Programa Minha Casa, Minha Vida; ii) implantar Programa de Fortalecimento da Cadeia Produtiva e Desenvolvimento de Fornecedores de Madeira e Móveis do Mercosul; iii) melhorar o posicionamento do Produto Brasileiro nos Mercados. As demais ações não lograram êxito.

Conforme exposto, a maior parte das ações e medidas da agenda do setor não obteve progresso, principalmente em virtude da falta de integração da cadeia produtiva do setor, não viabilizando as articulações em âmbito do Fórum de Competitividade (BRASIL, 2010). Mesmo assim, a indústria moveleira vislumbrou aumento na produção de $13,2 \%$ no período e ampliou o número de empregos e estabelecimentos, que passaram de 274 mil e 17,7 mil, respectivamente, para 298,4 mil e 18,9 mil (+8,9\% e $+6,77 \%)$ conforme MTE/RAIS. Por sua vez, o volume exportado teve desempenho negativo, passando de US\$ 988 milhões em 2008 para US\$ 789,3 milhões em 2010 (-20,1\%) (MOVERGS, 2014; MDIC, 2014).

\subsubsection{Plano Brasil Maior (PBM) - 2011}

O lançamento do PBM, em agosto de 2011, ocorreu em meio a um contexto negativo para o setor industrial: debates acerca da desindustrialização e reprimarização da pauta exportadora, bem como cenário internacional adverso (repercussão dos efeitos da crise de 2009). Nesse sentido, se, por um lado, o PBM possuía como vantagem a experiência de duas políticas anteriormente realizadas; por outro lado, encarava uma conjuntura internacional mais adversa (IEDI, 2011b).

Ao avaliar a PBM para o setor moveleiro, destaca-se que o Programa teve uma característica mais horizontal de política. Com isso, o setor de móveis acabou sendo beneficiado através dessa linha por meio, por exemplo, das desonerações fiscais, do acesso a linhas de crédito e de estímulos

${ }^{6}$ Para um detalhamento do desempenho dessa política ver IEDI (2011a). 
ao comércio exterior. Houve, no entanto, duas medidas voltadas especificamente ao setor: o Reintegra e a desoneração da contribuição patronal do INSS sobre a folha de salários ${ }^{7}$. A desoneração tem um papel importante em virtude dessa indústria ser intensiva em mão de obra, o que fortalece os ganhos de competitividade.

Uma medida relacionada à dimensão sistêmica "bem-estar do consumidor", que teve impacto no setor, foi o programa "Minha casa melhor", associado ao Programa Minha Casa Minha Vida, linha de crédito gerenciada pela Caixa, a qual disponibilizou cartão com crédito de até R\$ 5 mil para aquisição de móveis e eletrodomésticos com prazo de pagamento de 48 meses. Apesar da limitação do valor para compra de móveis (comparada com o valor para eletrodomésticos), a linha de crédito era uma reivindicação antiga do setor e contribuiu para ampliar o consumo de móveis.

Conforme dados da MOVERGS (2014), o desempenho do setor foi satisfatório, ampliando em 9,22\% de 2011 a 2013. A geração de empregos nesse período foi de cerca de 15 mil vagas e o número de estabelecimentos ampliou em 2,2 mil de acordo com MTE/RAIS (2014). Esse desempenho provavelmente é resultado da melhoria do mercado doméstico que manteve a expansão do setor imobiliário. No âmbito externo, o setor apresentou resultado negativo. A balança comercial do setor pela primeira vez observou resultados negativos. As exportações passaram de US\$742,6 milhões para US\$ 686,3 milhões e as importações passaram de US\$ 565,3 milhões para US\$ 744,4 milhões (MOVERGS, 2014; MDIC, 2014).

Em termos gerais, percebe-se que apesar do setor moveleiro vir mantendo investimentos e empregos nos últimos anos, o setor vem perdendo dinamismo no comércio exterior (GALINARI et al., 2013) Nesse sentido, verifica-se que os instrumentos utilizados pelas três políticas industriais para o setor de móveis não alcançaram os seus maiores objetivos, que se referiam a promover a inovação e a competitividade do setor (em termos de ampliar a competitividade nos mercados externos). Pode-se considerar que esse resultado é decorrente da falta de aderência entre as medidas das políticas com os principais gargalos da indústria, como matéria-prima e design, principais itens de inovação do setor. Por fim, não se verificou medidas mais específicas para prospectar novos mercados no exterior ou estimular a cadeia produtiva do setor.

\section{METODOLOGIA}

O setor moveleiro a ser estudado nesta pesquisa contempla as empresas que compõe o segmento da indústria de transformação (seção C) de fabricação de produtos de madeira (divisão 16) conforme Classificação Nacional de Atividade Econômica (CNAE) do IBGE. Ainda dentro dessa classificação, foram consideradas nesta pesquisa apenas as empresas pertencentes ao grupo 31 (fabricação de móveis), contemplando: fabricação de móveis de madeira, metal, outros materiais e colchões. Foram incluídas também as empresas que fabricam chapas de madeira compensada, laminada ou aglomerada e MDF do grupo 16 (desdobramento da madeira).

Para avaliar a relação entre as políticas industriais recentes e as estratégias de inovação da indústria moveleira, o presente trabalho lançou mão de pesquisa de campo mediante instrumento de entrevistas semiestruturadas em 14 empresas da região Oeste de Santa Catarina ${ }^{8}$. Os critérios para a seleção das empresas entrevistas foi, em primeiro lugar, que elas tivessem alguma experiência de

${ }^{7}$ O Reintegra é a devolução ao exportador de bens industrializados de até $3 \%$ do valor exportado (como compensação dos tributos indiretos incidentes sobre a produção).

${ }^{8}$ A mesorregião Oeste é composta por 118 municípios, divididos em cinco microrregiões: Chapecó, Concórdia, Joaçaba, São Miguel do Oeste e Xanxerê. 
exportação no período compreendido entre os anos de 2008 e 2013 (período escolhido em virtude da disponibilidade de dados pelo MDIC) conforme identificadas pelo MDIC (2014), sendo identificadas 54 empresas com essas características.

Desse conjunto de empresas, foi aplicado o método de amostragem por voluntários, que, segundo Richardson (2008), se refere a uma amostragem não-probabilística em que as unidades objeto de pesquisa aceitam/consentem em participar da amostra. Uma das situações em que esse método é utilizado refere-se quando os elementos de um grupo são difíceis de identificar e/ou contatar. Nesses termos, foram enviados convites para todas as 54 empresas através de email, em que 14 empresas aceitaram em participar da pesquisa, correspondendo a $26 \%$ do conjunto de 54 empresas selecionadas.

A escolha por firmas exportadoras decorre que este tipo de empresa ao estar mais exposta às exigências do mercado internacional, estariam mais inclinadas a investirem em inovação e mais atentas às ações governamentais, como por exemplo, a política industrial, objeto do trabalho. As entrevistas foram realizadas durante os meses de janeiro a março de 2015, contemplando empresas de municípios da região em um raio de 100 quilômetros em relação ao município de Chapecó-SC.

Dessa maneira, as entrevistas visaram, primeiramente, levantar informações acerca das características gerais dessas firmas e sua relação com os quesitos de inovação e competitividade. Em segundo lugar, de forma mais específica, analisar junto às firmas quais são seus diferenciais competitivos que as coloca no mercado internacional, bem como avaliar a política de inovação dessas empresas.

A partir do conhecimento da realidade das firmas moveleiras, parte-se por fazer as relações com as políticas industriais recentes, buscando verificar quais seriam os pontos em comum e de sustentação da política nacional para incentivar/fomentar as firmas da Região Oeste de Santa Catarina à busca constante por inovação e novos mercados.

Quadro 1 - Tipos de inovação que podem ser encontrados no setor de móveis conforme definição da literatura

\begin{tabular}{|l|l|}
\hline \multicolumn{1}{|c|}{ Tipo de inovação } & \multicolumn{1}{|c|}{ Caracterização/definição } \\
\hline 1) Inovação de produto & $\begin{array}{l}\text { Desenvolvimento de um produto novo da empresa, diferente de todos os } \\
\text { produtos que empresa já produziu. }\end{array}$ \\
\hline $\begin{array}{l}\text { 2) Alteração tecnológica } \\
\text { de produto }\end{array}$ & $\begin{array}{l}\text { Considera a melhoria de um produto já produzido pela empresa, cuja } \\
\text { performance foi substancialmente aumentada. Esse tipo de inovação inclui } \\
\text { alteração de matéria-prima e design. }\end{array}$ \\
\hline $\begin{array}{l}\text { 3) Inovação de processos } \\
\text { de produção }\end{array}$ & $\begin{array}{l}\text { Consiste na incorporação de novos métodos, procedimentos, sistemas, } \\
\text { máquinas ou equipamentos que diferem substancialmente daqueles } \\
\text { previamente utilizados pela empresa, ou seja, que causaram mudanças radicais } \\
\text { no processo de produção. }\end{array}$ \\
\hline $\begin{array}{l}\text { 4) Mudança tecnológica } \\
\text { nos processos de produção }\end{array}$ & $\begin{array}{l}\text { Consiste na incorporação de tecnologias parciais em processos previamente } \\
\text { adotados, como por exemplo, novas máquinas e equipamentos. }\end{array}$ \\
\hline $\begin{array}{l}\text { 5) Inovação } \\
\text { organizacional }\end{array}$ & $\begin{array}{l}\text { Contempla a introdução de novas técnicas de gestão, mudança na estrutura } \\
\text { organizacional (terceirização, qualidade, distribuição) nas práticas e nos } \\
\text { conceitos de marketing e de comercialização, formação de redes, bem como } \\
\text { novos métodos de gerenciamento. }\end{array}$ \\
\hline
\end{tabular}

Fonte: elaboração própria, a partir de Marion Filho e Sonaglio (2010). 
O questionário foi elaborado, considerando os principais elementos que fazem referência à inovação ao setor de móveis. Essas definições foram embasadas no estudo de Marion Filho e Sonaglio (2010) e de Rosa et al. (2007), e se referem a cinco quesitos, conforme apontados no Quadro 1.

\section{DADOS E RESULTADOS}

\subsection{Desempenho do setor de móveis no período recente?}

Segundo a MOVERGS (2014), a indústria brasileira do mobiliário apresentou crescimento anual, no período de 2009 a 2013, de 7,4\%, apresentando um valor de produção de R \$33,1 bilhões, em 2009, para R \$ 42,9 bilhões, em 2013. Essa expansão também pode ser verificada pela ampliação do número de pessoal ocupado, aumento de 25,9\% (259,7 mil empregos para 326,9 mil no período). Essa expansão decorre principalmente do aumento das vendas para o mercado doméstico, que se beneficiou da expansão do setor de construção civil e imobiliário.

Embora a indústria tenha verificado um bom desempenho internamente, a sua balança comercial inverteu o resultado. A expansão das exportações de móveis brasileiros verificada nos anos de 1990 a 2005 (crescimento de 2.400\%, conforme Rosa et al., 2007) era um indicador da competitividade dessa indústria. Nos últimos anos, porém, a balança comercial de móveis ficou deficitária. As exportações passaram de US\$ 692,5 milhões, em 2009, para US\$ 686,3 milhões, em 2013, e as importações passaram de US\$ 318,6 milhões para US\$ 744,4 milhões no mesmo período (MDIC/2014).

Tabela 1 - Número de empregos formais no setor de móveis da região Oeste de SC e comparativo com emprego total do setor de móveis de SC e com emprego total de SC - 2006 - 2013

\begin{tabular}{l|c|c|c|c|c|c}
\hline \multirow{2}{*}{ Produto } & \multicolumn{3}{c|}{ Empregos } & \multicolumn{3}{c}{ Estabelecimentos } \\
\cline { 2 - 7 } & $\mathbf{2 0 0 6}$ & $\mathbf{2 0 1 3}$ & $\begin{array}{c}\text { Var \% } \\
{[\mathbf{2 0 0 6 - 1 3}]}\end{array}$ & $\mathbf{2 0 0 6}$ & $\mathbf{2 0 1 3}$ & $\begin{array}{c}\text { Var \% } \\
{[\mathbf{2 0 0 6 - 1 3}]}\end{array}$ \\
\hline Madeira lam. e chapas compensados & 1.779 & 1.980 & 11 & 46 & 44 & $-4,4$ \\
Móveis de madeira & 6.470 & 7.809 & 21 & 443 & 485 & 9,5 \\
Móveis de metal & 82 & 297 & 262 & 14 & 19 & 35,7 \\
Móveis outros materiais & 288 & 149 & -48 & 14 & 20 & 42,9 \\
Colchões & 81 & 229 & 183 & 4 & 6 & 50,0 \\
\hline Total do Setor na região Oeste SC & 8.700 & 10.464 & 20,3 & 521 & 574 & 10,2 \\
\hline Total do Setor no Estado de SC & 37.228 & 37.603 & 1,0 & 2.181 & 2.740 & 25,6 \\
\hline part \% (setor Reg Oeste/Setor Estado SC) & 23,37 & 27,83 & 19,1 & 23,89 & 21,0 & $-12,3$ \\
\hline part \% (setor Reg Oeste/Empreg Total SC) & 0,54 & 0,47 & $-13,0$ & 0,3 & 0,3 & $-19,1$ \\
\hline part \% (Setor móveis de SC/Empr Total SC) & 2,33 & 1,70 & $-27,0$ & 1,4 & 1,3 & $-7,8$
\end{tabular}

Fonte: MTE/RAIS (2015). Elaboração própria.

\footnotetext{
${ }^{9}$ A diferença de períodos de análise nesta seção decorre da disponibilidade de dados das fontes pesquisadas.
} 
$\mathrm{Na}$ economia catarinense, a indústria moveleira tem uma participação importante, o estudo de Kroth et al. (2007), por exemplo, apontou que, para cada R \$ 1,0 de aumento na demanda de móveis, o setor gerava R\$1,3 de produto. Em termos de geração de emprego, o setor compreendia 2.740 estabelecimentos e empregava cerca de 37,6 mil pessoas no estado, em 2013, o que equivale a 1,7\% dos empregos formais do Estado, conforme Tabela 1. Apesar dessa importância, o setor perdeu participação no total de empregos do estado catarinense entre 2006 e 2013, passando de $2,33 \%$ para $1,70 \%$, e, no caso de estabelecimentos, a queda foi de $1,4 \%$ para $1,3 \%$. Tal desempenho foi proporcionado pelo impacto da crise econômica mundial de 2008, no qual o polo de São Bento Sul foi o mais prejudicado (LINS; MATTEI, 2010) ${ }^{10}$.

Na mesorregião Oeste de Santa Catarina, objeto da presente pesquisa, o setor de móveis apresentou evolução do seu Valor Adicionado de 40\% entre 2006 e 2012, conforme dados da Secretaria da Fazenda do Estado de SC (2014). Já o setor como um todo, no Estado catarinense, obteve crescimento de $13,3 \%$. A participação do setor de móveis da região Oeste sobre o setor de móveis catarinense passou de 25\%, em 2006, para 32\%, em 2012. Esse melhor desempenho da região Oeste em relação a outros polos do Estado, principalmente em relação ao polo de São Bento do Sul (maior polo), decorre principalmente do perfil das firmas e suas estratégias de vendas. Enquanto o polo de São Bento do Sul é muito dependente do mercado americano, o qual fabrica modelos de móveis predefinidos por empresas distribuidoras (trading companies), as firmas do Oeste são menos dependentes de um mercado externo específico e possuem maior autonomia no desenvolvimento de seus próprios produtos. Nesse sentido, o polo de São Bento do Sul sofreu um impacto negativo muito forte com a crise econômica mundial de 2008.

Em termos de geração de empregos, conforme Tabela 1, o setor de móveis da região Oeste foi responsável pela criação de mais de 10 mil empregos em 2013 - montante que equivale a pouco mais de 5\% do total de empregos formais da região Oeste SC. Ainda em termos de empregos, a região Oeste representa $28 \%$ do total de empregos do setor em SC, em 2013, e teve crescimento de mais de $20 \%$ no período de 2006 a 2013. A maior parcela dos empregos e dos estabelecimentos da região estão concentrados na fabricação de móveis de madeira, representando mais de $70 \% \mathrm{em}$ 2013, seguido de madeira laminada e chapas de compensado. Em que pese essa participação, os setores de móveis de metal e de colchões, foram os que mais cresceram no período $(+262 \%$ e $+183 \%$ na geração de empregos, respectivamente). Pode-se considerar que esse crescimento foi influenciado, por um lado, pela busca de novos nichos, como os móveis para escritório e escolares, incentivados pela demanda por parte do Governo e, por outro lado, pela busca de economias de escopo no processo produtivo, como é o caso dos colchões que podem servir para a fabricação de estofados.

\subsection{Resultados da pesquisa}

A apresentação dos resultados da pesquisa é dividida em três partes: caracterização das empresas entrevistas, estratégias de inovação e avaliação da política industrial.

\footnotetext{
${ }^{10}$ Segundo Cario et al. (2008), o estado de Santa Catarina possui vários polos moveleiros, em virtude da aglomeração de empresas do setor com destaque para as microrregiões de São Bento do Sul, Canoinhas, Blumenau, Joinville, Chapecó, São Miguel do Oeste e Joaçaba. As últimas três fazem parte da mesorregião Oeste.
} 


\subsubsection{Caracterização das empresas entrevistadas}

Das catorze empresas entrevistadas, uma possui porte de microempresa (até 19 empregados), oito são de pequeno porte (de 20 a 99 empregados), quatro são de médio porte (de 100 a 499 empregados) e uma é de grande porte (mais de 500 empregados). O segmento em que atuam é basicamente móveis residenciais (11 empresas), uma de colchões, uma de chapas de compensados e uma do segmento de móveis institucionais e portas. A matéria-prima mais utilizada é a madeira reflorestada de pinus (pinus elliottii), com $86 \%$ das empresas usando esse tipo de madeira, os painéis de madeira reconstituída (MDF) são utilizados por 50\% das empresas e a madeira de eucalipto, por $10 \%$. Os produtos derivados de "pinus" possuem mercados cativos no exterior (EUA e Europa) e no nordeste brasileiro, em virtude da preferência daqueles consumidores e pela maior resistência (principalmente em relação à umidade). A maior parte da matéria-prima é nacional, apenas três empresas importam.

Uma característica padrão das empresas entrevistas é que elas atuam há mais de dez anos no setor, sendo a mais antiga do ano de 1975 e a mais nova de 2003. Em média, as empresas possuem vinte e quatro anos. Com relação ao comércio exterior, dez empresas direcionam menos de $10 \%$ ao mercado externo e uma das empresas (pequeno porte) produz somente para a exportação. Outra característica é que somente seis empresas exportaram com regularidade nos últimos cinco anos. Apenas cinco empresas possuem metas de exportação, isto é, desejam acessar novos mercados no exterior ou ampliar o volume de suas vendas no exterior nos próximos anos.

\subsubsection{Estratégias de inovação das empresas}

As principais estratégias de inovação das empresas moveleiras da região Oeste Catarinense estão relacionadas, conforme o Quadro 2, com a introdução de novos métodos de produção, basicamente através da incorporação de novas máquinas e equipamentos, seguido de desenvolvimento de novos produtos, utilização de novas matérias-primas e introdução de Novos Processos de Gestão (NPG). Pode-se apontar ainda que as empresas estão constantemente incorporando melhorias em seus produtos e acompanham as tendências do mercado. Esse fato é reforçado à medida que nenhuma empresa respondeu que não realiza inovação. 
Quadro 2 - Tipos de inovação realizados pelas empresas do setor de móveis da região Oeste de SC

\begin{tabular}{|c|c|c|}
\hline $\begin{array}{l}\text { Nr. de } \\
\text { respostas }\end{array}$ & $\begin{array}{c}\text { Estratégia (ação) de inovação realizado pelas } \\
\text { empresas do mobiliário do Oeste de SC }\end{array}$ & $\begin{array}{c}\text { Tipo de inovação conforme } \\
\text { definição da literatura (Quadro 1) }\end{array}$ \\
\hline 13 & $\begin{array}{l}\text { NPG* }^{*} \text { novos métodos de produção - inclui } \\
\text { incorporação de máquinas }\end{array}$ & $\begin{array}{l}\text { Mudança tecnológica nos processos } \\
\text { de produção }\end{array}$ \\
\hline 10 & Novos produtos (inclui design) & $\begin{array}{l}\text { Inovação de produto/Alteração } \\
\text { tecnológica de produto }\end{array}$ \\
\hline 10 & Novos insumos/matérias-primas & Alteração tecnológica de produto \\
\hline 7 & NPG: gestão & Inovação organizacional \\
\hline 7 & NPG: qualidade do produto & Inovação organizacional \\
\hline 6 & $\begin{array}{l}\text { Novos mercados consumidores (no país e/ou no } \\
\text { exterior) }\end{array}$ & Inovação organizacional \\
\hline 4 & $\begin{array}{l}\text { Melhoria/incorporação do design de produtos } \\
\text { existentes }\end{array}$ & Alteração tecnológica de produto \\
\hline 3 & NPG: logística & Inovação organizacional \\
\hline 3 & NPG: terceirização & Inovação organizacional \\
\hline 3 & $\begin{array}{l}\text { Parcerias entre empresas do setor, fornecedores } \\
\text { e/ou distribuidores }\end{array}$ & Inovação organizacional \\
\hline 0 & Não realiza inovação. & \\
\hline
\end{tabular}

Fonte: elaboração própria a partir de dados da pesquisa. *NPG: Novos Processos de Gestão

Obs: O número de respostas é maior do que o número de empresas entrevistas, em virtude de que cada empresa poderia responder mais do que uma opção.

Com relação aos novos métodos de produção, as empresas passaram a incorporar máquinas importadas que permitiram melhorias na automação de processos e, consequentemente, redução da dependência de mão de obra, cada vez mais escassa na região. Segundo os empresários, a incorporação dessas máquinas poderia ser maior, caso houvesse menores dificuldades na importação (em termos de tributação e trâmites burocráticos). A falta de mão de obra qualificada também é um obstáculo para a maior utilização de tecnologia nas fábricas. Destaca-se que há uma diferença importante nessa estratégia, considerando o perfil das empresas. Enquanto as empresas maiores importam máquinas de última geração da Europa, as de micro e pequeno porte acabam incorporando máquinas fabricadas nacionalmente, ou ainda adquirindo máquinas usadas de empresas concorrentes de maior porte.

O desenvolvimento de novos produtos é realizado, na maioria das vezes, de forma marginal, com atualização dos produtos que já vem sendo fabricados pela empresa. Portanto, na maioria dos casos, o desenvolvimento de um novo produto pela firma decorre de um aprimoramento do produto existente, sendo estes casos classificados como "Alteração tecnológica de produto". Destaca-se que apenas as maiores empresas (quatro médias e uma grande) possuem equipes próprias de design ou terceirizadas para desenvolver novos produtos e apenas três delas possuem patentes de suas inovações ${ }^{11}$.

Um elemento que afeta diretamente o potencial inovador das empresas é a presença de intermediários (trading companies) de redes de lojas dos EUA e da Europa, que apenas contratam a produção de móveis a partir de modelos pré-estabelecidos pelos lojistas. Na presente amostra, três empresas (duas de pequeno e uma de médio porte) se enquadram nesse formato de vendas. Nesse terreno, os móveis de pinus podem ser considerados uma commodity no mercado internacional,

${ }^{11}$ Segundo os entrevistados, a morosidade e a insegurança jurídica desincentivam e diluem a importância da patente como proteção à empresa inovadora. 
muitas empresas brasileiras e estrangeiras produzem tal produto, que exige pouca inovação. As empresas produtoras inovam nos processos para baixar custos, pois os modelos e preços vêm prontos dos lojistas do exterior, dando pouca margem de manobra para as empresas alterarem o produto. Nessa conjuntura, o Brasil é competitivo por conta da existência e baixo preço da madeira.

A introdução de NPG é a estratégia de inovação mais disseminada entre todas as empresas, independente do seu porte e abrange várias áreas da gestão de negócios, como, por exemplo: gestão de custos, gestão de processos produtivos (terceirização e qualidade do produto), logística e marketing. Ainda com relação à gestão, há a introdução constante de novos métodos gerenciais e profissionalização da gestão. Em termos de qualidade, há uma preocupação em incorporar insumos sofisticados e aplicar normas de segurança, a exemplo de normatização do Inmetro em determinados produtos. Nesse item, chamou a atenção o papel que a transição geracional vem assumindo nessas empresas. Em que pese o perfil familiar preponderante, observou-se que em dez empresas a responsabilidade da gestão dos negócios está na mão dos filhos dos proprietários, a maioria com cursos técnico ou superior. Pode-se considerar que essa característica da gestão acaba contribuindo para a incorporação de inovações dentro das firmas, dado que os jovens estão mais inclinados a incorporar mudanças e novas tendências do setor.

Em termos de prospecção de novos mercados consumidores, verificou-se que o mercado externo vem sendo colocado em segundo plano pelas empresas regionais, resultado da expansão do setor imobiliário no país nos anos 2000 e da queda da rentabilidade e da demanda externa (câmbio apreciado e crise americana). Para dar vazão a essa ampliação do mercado doméstico, principalmente para o segmento popular, as empresas investiram em renovação do parque de máquinas, visando o aumento da produtividade e a redução de custos. Além disso, muitas empresas alteraram ou criaram novos produtos, tais como modulados e linha infantil. Também há casos que as empresas diversificaram sua linha produtos, incorporando produtos de construção civil, como é o caso de portas. Destaca-se que as empresas da região acabaram se beneficiando da retração do setor imobiliário americano, na medida que a demanda por matéria-prima (madeira de pinus) no mercado nacional reduziu, resultando em redução no preço do seu principal insumo.

Em síntese, pode-se apontar como principais inovações das empresas de móveis da região Oeste Catarinense no período sob análise: i) o lançamento de novas linhas de produtos para nichos específicos, como por exemplo a linha infantil, incorporando selos de segurança do Inmetro ${ }^{12}$; ii) utilização de novos modais logísticos, como a incorporação da cabotagem na distribuição de móveis no país (sentido sul-norte e sul-nordeste); iii) a profissionalização da gestão: introdução de novos métodos gerenciais e sucessão familiar; e, iv) incorporação de máquinas e matérias-primas.

Considerando a classificação proposta por Marion Filho e Sonaglio (2010), exposta no Quadro 01, as estratégias de inovações apontadas se enquadram nas classes "alteração tecnológica de produto" e "mudança tecnológica nos processos de produção" e, em menor grau, "inovação organizacional". Essas inovações, que podem ser consideradas inovações marginais, são facilitadas principalmente pela experiência dessas empresas no setor, tendo em vista que a idade média das firmas é de 24 anos. Destaca-se ainda que, comparando com o perfil de inovação geral do setor, conforme exposto em Galinari et al. (2013), as empresas de móveis do Oeste de Santa Catarina se aproximam da média nacional.

\footnotetext{
${ }^{12}$ As exigências do Inmetro para a linha infantil no Brasil são maiores que as exigidas pelo órgão de segurança europeu e americano, o que garantiu para as empresas da Região Oeste novos mercados no exterior.
} 
Quadro 3 - Modalidades de acesso a inovações e tendências do setor de móveis conforme entrevista realizada com empresas do setor de móveis da região Oeste SC

\begin{tabular}{|c|l|}
\hline $\begin{array}{c}\text { Número de } \\
\text { respostas }\end{array}$ & \multicolumn{1}{c|}{ Modalidades } \\
\hline 11 & Feiras nacionais \\
\hline 6 & Outro: Lojista/representante comercial sugere novos atributos no produto \\
\hline 6 & Feiras internacionais \\
\hline 5 & Revistas, publicações e sites especializados \\
\hline 4 & A própria empresa cria inovações e tendências no setor \\
\hline 3 & Pesquisa de mercado (comportamento do consumidor) \\
\hline 3 & Consultorias específicas (processos, tendências e modas) \\
\hline
\end{tabular}

Fonte: elaboração própria a partir de dados da pesquisa.

Obs: O número de respostas é maior do que o número de empresas entrevistas, em virtude de que cada empresa poderia responder mais do que uma opção.

Um segundo quesito analisado no âmbito das estratégias de inovação das empresas, refere-se aos canais de acesso às inovações e às novas tendências do setor, conforme exposto no Quadro 3. Nesse aspecto, a participação em feiras nacionais se sobressaiu, sendo as feiras de Bento Gonçalves-RS e a de Arapongas-PR as mais frequentadas. Outra feira importante é a Mercomóveis de Chapecó-SC, organizada pelo Sindicato da Indústria Madeireira e Moveleira do Vale do Uruguai (SIMOVALE). Com relação às feiras de máquinas, a mais visitada é a FIMMA, de Bento Gonçalves. Enquanto nas feiras do Paraná e Rio Grande do Sul geralmente são as empresas maiores que acabam expondo, na feira regional (Mercomóveis) a participação é geral: doze empresas da amostra expõem seus produtos com regularidade. As feiras internacionais, principalmente em termos de visitação, foram apontadas como o segundo canal mais importante. Das seis respostas, uma se refere à empresa de grande porte, duas de médio e três de pequeno porte. Dessas feiras, destacam-se as da Alemanha, EUA, Itália e China.

Também em segundo lugar, aparece o quesito "lojista ou representante comercial que sugere inovações", isto é, o feedback do consumidor acaba sendo um dos pontos fortes e estratégicos para as empresas realizarem modificações no seu produto ou fazer o lançamento de novos móveis no mercado. Nesse sentido, dado que a experiência dessas empresas é o principal fator que determina suas inovações, conforme exposto anteriormente, pode-se considerar, ainda, que o processo de learning by interacting acaba sendo complementar e estratégico para as inovações, principalmente para as micro e pequenas empresas, as quais não possuem equipes próprias de desenvolvimento de novos produtos.

Nesse âmbito, verifica-se que somente quatro empresas (o que representa 28,5\% da amostra) responderam que "a própria empresa cria seus produtos e tendências no setor". As principais características dessas empresas é que elas possuem porte médio e grande, possuem departamentos internos de design e/ou agências de design terceirizadas, realizam constantes investimentos em tecnologia e novos insumos e possuem gestão profissionalizada.

Dentro do escopo das estratégias e canais de acesso à inovação, as parcerias com outras empresas do setor não foi apontado como preponderante. A maioria das empresas não realiza ou realiza parceria de forma muito superficial com as demais empresas do setor, demonstrando a pouca 
cooperação dessas empresas, mesmo estando geograficamente próximas e/ou estando associadas a um mesmo sindicato. Essa falta de cooperação do setor na região pode ser considerada um imperioso obstáculo para a geração de inovações e ganhos de competitividade das empresas regionais, sobretudo de micro e pequeno porte, pois deixam de obter as vantagens de eficiência coletiva, conforme apontadas por Schmitz (1997). Nessa seara, identifica-se que embora haja uma boa concordância por parte da literatura e de instituições acerca dos benefícios de ações coletivas, não se percebe o mesmo entusiasmo em termos de encampar projetos dessa natureza na região. Essa realidade regional também é verificada em nível de Brasil (GALINARI et al., 2013).

Por fim, destaca-se que, embora ocorram inovações e haja uma preocupação em termos de inserir inovações nos produtos pelas firmas da Região Oeste, não se observou a existência de uma política e cultura de Pesquisa e Desenvolvimento (P\&D) por parte das firmas pesquisadas. Nesse quesito, apenas duas empresas (uma grande e uma média) responderam que direcionam permanentemente o percentual de $2 \%$ de seu faturamento para inovação, enquanto três responderam que inovam constantemente seus produtos (uma média e duas pequenas), conforme percepções do mercado. Embora extremamente relevante para $\mathrm{P} \& \mathrm{D}$, praticamente inexiste parcerias com universidades, institutos de pesquisa ou entre si. As empresas de maior porte (grandes e médias) estão mais focadas em P\&D e possuem metas em serem líderes em determinados segmentos, investindo constantemente em produtos e processos de forma individualizada. Por fim, cabe salientar que é incipiente o investimento dentro das estratégias de NPG por parte das firmas entrevistadas, da formação ou existência de planos de carreira para a mão de obra. Esse tema é relevante para as estratégias de inovação das firmas, tendo em vista que, por um lado, há escassez de mão de obra para o setor na região e, por outro lado, essa indústria é intensiva em mão de obra.

Dessa maneira, a maior parte das empresas entrevistas (80\% da amostra) realiza e/ou incorpora inovações mediante exigências do mercado, sendo que as empresas de maior porte possuem maior protagonismo e investimentos em processos inovativos. Por outro lado, as micro e pequenas empresas direcionam seu esforço para incorporar inovações em seu produto, a medida que ocorre pressão por parte do mercado, num processo conhecido como learning by interacting. Pode ser apontado que a principal motivação para a introdução de inovações é a busca por ganhos de competitividade (redução de custos). $\mathrm{O}$ apelo à competitividade é justificada pela característica dessa indústria regional, intensiva em mão de obra (que no momento encontrava escassa e com alto custo) e a distância dos principais centros consumidores e de fornecedores de insumos, o que encarece seus produtos.

\subsubsection{Avaliação da política industrial}

A análise desta subseção tem como objetivo avaliar as ações desenvolvidas para o setor de móveis pelas três políticas industriais desenvolvidas entre 2003 a 2014, conforme apontado na seção 2.2, e também levantar sugestões de medidas que poderiam ser implementadas no aprimoramento da política industrial e de inovação.

Em termos de avaliação das políticas, verificou-se que duas empresas consideraram que as ações contribuíram totalmente para sua empresa inovar (uma grande e uma pequena); sete empresas avaliaram que as ações foram relevantes (duas médias e cinco pequenas), mas ainda insuficientes; e cinco empresas apontaram que as ações tiveram pouca importância (duas médias e três pequenas). Nenhuma empresa entrevistada avaliou que as ações não tiveram nenhuma contribuição. 
Com relação à insuficiência ou pouca importância das ações, foi destacado que algumas medidas, como a redução de IPI para móveis, trouxe pouco benefício para o setor industrial, dado que em muitos casos não houve o repasse por parte do comerciante do desconto do IPI para o consumidor final. Nesse caso, o subsídio ampliou apenas a margem de lucro do comerciante. Com relação às linhas de crédito para aquisição de tecnologias do BNDES, há ainda muitos obstáculos para o acesso de empresas de menor porte. Por fim, a linha de crédito "Minha Casa Melhor", beneficiou em maior medida à linha de eletrodomésticos, uma vez que os limites para aquisição de móveis eram muito baixos.

Ao avaliar as sugestões de melhoria e aprimoramento da política industrial para o setor, o Quadro 4 apresenta a síntese dos resultados. Essas propostas se referem a ações e processos que são considerados mais relevantes para realizar inovação no setor de móveis. Dessa maneira, duas ações foram apontadas como mais importantes: "qualificação da mão de obra" e "subsídios governamentais". A primeira decorre tanto pela falta de mão de obra em termos de quantidade como em termos de qualidade.

Quadro 4 - Ações necessárias para as empresas inovarem conforme entrevista com empresas do setor de móveis da região Oeste SC

\begin{tabular}{|c|l|}
\hline Número de respostas & \multicolumn{1}{c|}{ Ações/medidas } \\
\hline 11 & Qualificação da mão de obra \\
\hline 11 & Subsídios governamentais (redução da carga tributária) \\
\hline 9 & Recursos (crédito) \\
\hline 7 & Infraestrutura (rodovias/ferrovias, portos, energia) \\
\hline 6 & Acesso facilitado a novas tecnologias \\
\hline 6 & Redução da burocracia \\
\hline 5 & Taxa de câmbio competitiva (muita oscilação) \\
\hline 3 & $\begin{array}{l}\text { Suporte técnico e/ou centro de pesquisas exclusivo para o } \\
\text { setor }\end{array}$ \\
\hline 2 & Tradding companies e/ou centros distribuidores no exterior \\
\hline
\end{tabular}

Fonte: elaboração própria a partir de dados da pesquisa.

Obs: O número de respostas é maior do que o número de empresas entrevistas, em virtude de que cada empresa poderia responder mais do que uma opção.

Com relação aos subsídios governamentais há duas questões principais. A primeira questão se refere a necessidade de redução da carga tributária sobre os salários, a qual gera um peso muito grande sobre os custos, tendo em vista que tais firmas são intensivas em trabalho. Alinhado a essa questão, há uma crítica dos empresários em relação a outras exigências trabalhistas, como a adequação à Norma Regulamentadora nr. 12 (NR 12) do Ministério do Trabalho, pois além do baixo período para adaptação à normativa, a qual exige mudanças no parque de máquinas e layout produtivo, não há linhas de crédito e/ou subsídios para realizar tais alterações. A segunda questão concerne às ações de redução da carga tributária para o setor em âmbito das políticas industriais, realizadas com mais intensidade pós-2008, visto que não reverteram diretamente para a indústria, 
mas acabaram sendo absorvidas pelo comércio. Outro aspecto, tange à demora do Governo em devolver os créditos tributários derivados das isenções sobre exportações.

Outras ações importantes para inovar se referem a linhas de crédito, com ênfase para capital de giro e redução do custo total do crédito, ou seja, não apenas relacionada com a taxa de juros, mas com outros custos, como tarifas e exigências bancárias. A melhoria da infraestrutura também foi bastante apontada como necessidade, decorrente do fato de a região Oeste estar distante de portos e principais mercados consumidores do país, gerando custos adicionais para as empresas. Os exemplos mais delicados nessa linha são a precariedade da malha rodoviária que liga a região aos portos e a falta e baixa qualidade de energia elétrica. Esse último elemento vem causando sérios problemas para as empresas regionais, inclusive inibindo novos investimentos.

Considerando as ações e medidas apontadas no Quadro 4, as principais sugestões de melhoria da política podem ser divididas em ações verticais e em ações horizontais. Em termos de ações verticais, isto é, específicas para o setor de móveis, a redução do custo trabalhista e a qualificação da mão de obra se sobressaem. Nesse sentido, apesar da qualificação da mão de obra ser muito citada, medidas mais específicas para melhorar essa qualificação não foram citadas. Ao comparar essa exigência do setor com a política de capacitação interna das firmas, percebe-se que há uma falta de compreensão sobre como tornar essa mão de obra mais qualificada e contributiva do ponto de vista da inovação. Outra medida de cunho vertical, diz respeito às linhas de crédito para o setor, principalmente para micro e pequenas empresas, as quais enfrentam ainda muitas restrições ao acesso do crédito. Por fim, apenas três empresas (duas pequenas e uma média) citaram a necessidade de implementar um centro de pesquisas para o setor na região, o que só corrobora a cultura de baixo investimento em P\&D e de cooperação, conforme apontado anteriormente.

Em termos de ações horizontais (ações de natureza macroeconômica), as maiores sugestões vão ao encontro da redução do chamado "custo Brasil”, ou seja, redução da carga tributária, redução da burocracia e melhoria da infraestrutura; e de uma maior estabilidade macroeconômica, principalmente em termos de taxa de câmbio. A sugestão por uma agenda de ações horizontais reflete o exposto pela literatura em termos da necessidade da política macroeconômica se alinhar com a política industrial. Ao analisar as proposições de melhoria da política industrial para o setor de móveis, percebe-se certa distância entre os macroobjetivos da política industrial (principalmente no quesito busca pela competitividade) e os anseios das empresas, dado que as empresas almejam ações diferentes e/ou não possuem incentivos para se engajarem nos macroobjetivos da política industrial.

Nesse sentido, ao considerar as três partes da pesquisa, pode-se avaliar que as ações e instrumentos utilizados pelas três políticas industriais pouco contribuíram para ampliar a inovação no setor e muito menos viabilizou ampliar a participação dessas firmas no mercado internacional. As ações das políticas industriais possibilitaram manter o alargamento do mercado doméstico, garantindo, assim, a geração de empregos, mas sem contrapartidas por parte da indústria do mobiliário nas áreas de inovação e comércio exterior.

\section{CONCLUSÃO}

O Brasil retomou, a partir de 2003, a realização de políticas industriais visando a dinamizar alguns setores considerados estratégicos e ampliar a competitividade geral da indústria. Foram lançadas três políticas: PITCE (2004), PDP (2008) e PBM (2011), que tiveram como principais pontos positivos a retomada da agenda da política industrial no país e a construção de um arranjo 
institucional. Como pontos a serem aprimorados, destacam-se a necessidade de alinhar as ações/diretrizes das política industriais e macroeconômica, o aprimoramento e ampliação de instrumentos de cunho setorial para setores específicos e avançar na governança da política.

O setor de móveis passou a ser contemplado mais especificamente com o PDP (2008) e PBM (2011), embora as ações estivessem mais voltadas a demandas pontuais do ambiente de negócios e não atingiram os principais gargalos da indústria, como matéria-prima (incluindo ferragens) e design, principais itens de inovação do setor, bem como houve poucas iniciativas e avanços na área do comércio exterior e na competitividade da cadeia produtiva da indústria. Observou-se ainda que a articulação entre setores do Governo com as entidades de classe devem ser aprimoradas.

Ao avaliar as ações realizadas e/ou os instrumentos utilizados pelas políticas industriais junto com as empresas do setor da região Oeste de Santa Catarina, verificou-se que as políticas pouco contribuíram para ampliar a inovação no setor e muito menos viabilizou ampliar o volume de exportações. Em geral, percebeu-se que as ações possibilitaram manter o alargamento do mercado doméstico, garantindo, assim, a geração de empregos, mas sem contrapartidas por parte da indústria nas áreas de inovação e comércio exterior.

Dessa forma, as empresas regionais realizaram inovações apesar da política industrial, com o principal objetivo de ampliar competitividade no mercado doméstico, ou seja, a estratégia de redução de custos é primordial para essa indústria, tendo em vista que os principais componentes de seu custo $r$ se relacionam às áreas logística e trabalhista. Esse perfil do setor de móveis da Região Oeste de Santa Catarina se aproxima muito do perfil encontrado no restante do país, conforme pesquisa realizada por Galinari et al. (2013), ou seja, houve pouco investimento em P\&D para buscar mercados externos e o foco ficou direcionado para a expansão do mercado doméstico e há pouca cooperação entre empresas do setor.

Como principais inovações da indústria, considerando a classificação proposta por Marion Filho e Sonaglio (2010), foram "alteração tecnológica de produto" e "mudança tecnológica nos processos de produção" e em menor grau "inovação organizacional”, que podem ser consideradas inovações marginais. Mais especificamente, as principais inovações dizem respeito a: i) lançamento de novas linhas de produtos para nichos específicos; ii) novos métodos logísticos, como a incorporação da cabotagem na distribuição de móveis no país; iii) profissionalização da gestão; e, iv) incorporação de máquinas e matérias-primas.

Essas inovações são viabilizadas pela experiência dessas empresas no setor, a idade média das empresas ultrapassa 20 anos de atuação no mercado, o que sugere a apontar um processo de aprendizagem, através da utilização dos recursos empresariais e da rotinização das atividades, indo ao encontro dos postulados evolucionários de Penrose (1959) e Nelson e Winter (1982). Há também o processo de learning by interaction, devido aos feedbacks dados pelos lojistas e representantes comerciais.

Por fim, a indústria considera que as ações de política industrial para o setor foram relevantes, mas ainda são insuficientes. Como proposições para aprimoramento da política industrial, a pesquisa indicou a necessidade da realização de programas de "qualificação da mão de obra" e de "subsídios governamentais", bem como ampliação de "linhas de crédito subsidiadas" (tanto para investimento como para capital de giro) e "melhoria na infraestrutura".

Embora a presente pesquisa tenha elucidado algumas questões relacionadas aos efeitos das políticas industriais recentes do setor de móveis regional, o trabalho sofre de limitações em virtude 
da pequena amostra da pesquisa e por direcionar seu foco para firmas exportadoras. Em vista disso, sugere-se que as pesquisas do setor deveriam abranger um grupo maior de empresas, bem como realizar comparativos com empresas de outras regiões do Estado, que também possuem polos, a fim de ampliar a compreensão sobre os processos inovativos dessa indústria.

\section{REFERÊNCIAS}

ASSOCIAÇÃO DAS INDÚSTRIAS DE MÓVEIS DO ESTADO DO RIO GRANDE DO SUL (MOVERGS). Relatório setorial 2014. Disponível em:http://www.movergs.com.br/views/ imagempdf.php?pasta=relatorio_setorial2014 Acesso em: 20dez2014.

BRASIL. Ministério do Desenvolvimento Indústria e Comércio. Política de Desenvolvimento Produtivo - PDP. Brasília, 2008a. Disponível em: http://www.desenvolvimento.gov.br/pdp/ index.php/sitio/conteudo/conteudo/1/0/18. Acesso em: 08jan2015.

. Ministério do Desenvolvimento Indústria e Comércio. Política de Desenvolvimento Produtivo - PDP. Balanço de atividades 2008/2010, v. 3, Brasília, 2010. Disponível em: http://www.pdp.gov.br/ Relatrios/Resumo\%20Executivo_vers\%C3\%A3o\%20final.pdf. Acesso em: 08 jan2015.

. Plano Brasil Maior: inovar para competir, competir para crescer. Brasília, 2011. Disponível em: http://www.brasilmaior.mdic.gov.br/conteudo/ 129. Acesso em: 08jan2015.

CANO, W.; SILVA, A. L. G. Política industrial do governo Lula. Texto discussão Unicamp, n. $181,2010$.

CARIO, S. A. F. et al. (Orgs.) Economia de Santa Catarina: inserção industrial e dinâmica competitiva. Blumenau, Nova Letra, 2008.

CIMOLI, M.; DOSI, G.; STIGLITZ, J. (org). Industrial policy and development: the political economy of capabilities accumulations. Oxford: Oxford University Press, 2009.

DOSI, G.; NELSON, R. R. An introduction to evolutionary theories in economics. Journal of evolutionay economics, n. 4, pp. 153-172, 1994

GALINARI et al. A competitividade da indústria de móveis do Brasil: situação atual e perspectivas. BNDES setorial, n. 27, pp. 227-272, BNDES, mar/2013. Disponível em:

https://web.bndes.gov.br/bib/jspui/bitstream/1408/1516/1/A\%20mar37_06_A\%20competitividade $\% 20 \mathrm{da} \% 20$ ind $\%$ c3\%bastria\%20de\%20m\%c3\%b3veis\%20do\%20Brasil_P.pdf. Acesso em $12 \mathrm{jan} 2015$.

HODGSON, G. M. Reclaiming habit for institucional economics. The Journal of Economic Psychology, v. 25, p. 651-660, 2004.

INSTITUTO DE ESTUDOS PARA O DESENVOLVIMENTO INDUSTRIAL (IEDI). Indústria e política industrial: no Brasil e em outros países. Maio/2011a. 
. Uma análise do Plano Brasil Maior. Carta IEDI, n. 486, 23/09/2011b. Disponível em:

http://www.iedi.org.br/cartas/carta_iedi_n_486_uma_analise_do_plano_brasil_maior.html. Acesso em: 12 jan2015

KROTH, D. C. et al. A indústria moveleira da Região Sul do Brasil e seus impactos na economia regional: uma análise em Matriz de Insumo-Produto Multirregional. Ensaios FEE, v. 28, n. 2, p. 497-524, out/2007

LINS, H. N.; MATTEI, L.. Liberalização econômica e reestruturação produtiva: reflexos em Santa Catarina no limiar do novo século. In: MATTEI, L.; LINS, H. N. (orgs.). A socioeconomia catarinense: cenários e perspectivas no início do século XXI. Chapecó, SC: Argos, 2010. p. 109 -155 .

LUNDVALL, B. Innovation as an interactive process: from user-producer interction to the national system of innovation. IN: DOSI, G. et al., (eds) Technical Change and Economic Theory,

London, Pinter Publishers. 1988.

MARION FILHO, J. P.; SONAGLIO, C. M. Inovações tecnológicas na indústria de móveis: uma avaliação a partir da concentração produtiva de Bento Gonçalves (RS). Revista Brasileira de Inovação, n. 9, v. 1, p. 93-118, jan-jun/2010.

MALERBA, F. Learning by firms and incremental technical change. Economic Journal, 102, pp. 845-59, 1992.

MALERBA, F.; ORSENIGO, C. Technological Regimes and Firm Behavior. IN: DOSI, G.; MALERBA F. (ed.). Organization and strategy in the evolution of the enterprise. Macmillan Press, 1996.

MELO, T. M. et al. Política industrial como política de inovação: notas sobre hiato tecnológico, políticas, recursos e atividades inovativa no Brasil. Revista Brasileira de Inovação, v. $14 \mathrm{n}$. especial, p. 11-36, jul/2015.

METCALFE, J. S. Evolutionary economics and technology policy. The Economic Journal, v. 104, n. 425, pp. 931-944, jul/1994.

NELSON, R.; WINTER, S. An Evolutionary Theory of Economic Change, Harvard University Press, 1982.

OREIRO, J.L; FEIJÓ, C. A. Desindustrialização: conceituação, causas, efeitos e o caso brasileiro. Revista de Economia Política, vol. 30, n.2, abr/2010

O’SUlLIVAN, E.; ANDREONI, A.; LÓPEZ-GÓMEZ, C.; GREGORY, M. What is new in the new industrial policy? A manufacturing systems perspective. Oxford Review of Economic Policy, v. 29, n. 2, pp. 432-462, 2013

PENROSE, E. A teoria do crescimento da firma. SP: Hucitec, 2006 (1959).

RICHARDSON, R. J. Pesquisa social: métodos e técnicas. $3^{\text {a }}$ ed. SP: Atlas, 2008

RODRIK, D. One Economics, many recipes: globalization, institutions and economic growth, Princeton University Press, 2007, 257p. 
ROSA, S. E. S. da et al. O setor de móveis na atualidade: uma análise preliminar. BNDES setorial, n. 25 , pp. $65-106, \operatorname{mar} / 2007$

SANTA CATARINA. Secretaria do Estado da Fazenda. Indicadores da Administração Tributária. Arrecadação por município e por região do Estado. Disponível em: http://www.sef.sc.gov.br/relatorios/diat/arrecada\%C3\%A7\%C3\%A3o-por-munic\%C3\%ADpio-epor-regi\%C3\%A3o-do-estado Acesso em: 20jan2015.

SHAPIRO, M. G. Ativismo Estatal e Industrialismo Defensivo: instrumentos e capacidades na política industrial brasileira. Texto para discussão IPEA, n. 1856, ago/2013

SCHMITZ, H. Eficiência coletiva: caminho de crescimento para a indústria de pequeno porte. Ensaios FEE, Porto Alegre, v. 18, n. 2, p.164-200, 1997

SCHUMPETER, J. Teoria do desenvolvimento econômico. SP: Nova Cultural, 1985 (1911).

SUZIGAN, W.; FURTADO, J. Política industrial e desenvolvimento. Revista de Economia Política, v. 26, n. 2 (102), pp. 163-185, abr-ju/2006 - Instituições e políticas industriais e tecnológicas: reflexões a partir da experiência brasileira. Revista Estudos Econômicos, v. 40, n. 1, pp. 7-41, jan-mar/2010

VERMULM, R. Política industrial, tecnológica e de comércio exterior. IEDI, RJ: jul/2004 